\title{
Imaginarios culturales y \\ o emocionales \\ a través de expresiones \\ narrativas populares
}

\author{
Anna María Fernández Poncela \\ Universidad Autónoma de México, Xochimilco
}

Resumen: Aquí se presenta un panorama general en torno a las leyendas en la ciudad de México actualmente. A través de un amplio cuestionario cualitativo y cuantitativo aplicado entre la población, se revisan estos relatos orales, su tipología, características, contexto social, y las emociones que las acompañan. Se muestra la relación entre cultura y emoción en las leyendas, así como, su vigencia en nuestros días.

Palabras clave: leyendas, emociones, cultura, México.

Abstract: Here is a general overview of legends in general in Mexico City today. These oral histories, their typology, characteristics, social context, and accompanying emotions are reviewed through a broad qualitative and quantitative questionnaire applied among the population. The relationship between culture and emotion is shown in the legends, as well as their validity in our days.

Key words: legends, emotions, culture, Mexico. 


\section{Introducción}

La historia es imposible e inconcebible fuera de la imaginación productiva o creadora, de lo que hemos llamado lo imaginario radical tal como se manifiesta a la vez e indisolublemente en el hacer histórico, y en la construcción, antes de toda racionalidad explícita, de un universo de significaciones (Castoriadis, 1975, p. 253).

En estas páginas pretendemos revisar las leyendas tradicionales y contemporáneas, vigentes en la actualidad, su tipología y contexto social, así como los sentimientos que despiertan. Una primera aproximación al análisis e interpretación de este fenómeno social ligado al imaginario, las representaciones sociales, la cultura y la psique, y al mundo emocional.

Partimos de varias ideas ${ }^{1}$ : en primer lugar, las expresiones y relatos culturales están intrínsecamente ligados a aspectos sociales, culturales y emocionales, individuales, interrelacionales y grupales, psíquicos y sociales.

En segundo lugar, son parte del conocimiento social y de la comunicación moral emotiva, con textos multisemánticos y poliemotivos (Rodrigo y Medina, 2010). Como parte del conocimiento presentan funciones semejantes a las representaciones sociales, reproducen conocimientos, son modelos de interpretación que pueden guiar acciones, clasifican, orientan, interpretan y justifican comportamientos, fortalecen identidades, formas de expresión de grupos y transformaciones sociales (Jodelet, 1985). Como parte de la comunicación, proveen de sentido a los cambios y a la pertenencia, a la memoria colectiva y la identidad social. Son símbolos que marcan fronteras, al mismo tiempo que hacen circular mensajes dentro de una comunidad o al exterior, en su caso. Toda vez que son parte de la comunicación afectiva o emotiva (Marty y Jenney cit. Gutiérrez y Plantin, 2010) que influye en la relación intersubjetiva (Rodrigo y Medina 2010) y en el interlocutor/a; constituyendo expresiones emocionales verdaderas y espontáneas (Frijda cit. Gutiérrez y Plantin, 2010).

En tercer lugar, su estudio redunda en conocimiento social, de los imaginarios (Castoriadis, 1975, 1988; Durand, 2000) y representaciones sociales de nuestra cultura, en el contexto de la reproducción social (Moscovici, 1976; Ibáñez, 1988) y también de la estructura del sentimiento social (Rodrigo y Medina, 2010). Es decir, pueden ser 
consideradas como una suerte de termómetro social, una metáfora social, reflejo cultural y emocional de la comunidad y su existencia, ya que reflejan la psique y la cultura, al mismo tiempo que la configuran y co-construyen. Proyección e interiorización de temores, descargas emocionales y reproducciones e introyecciones culturales.

En cuarto lugar, hoy hay una vigencia importante de la tradición oral en la era de la globalización, de los modernos medios de comunicación de masas y de las nuevas tecnologías de la información. En parte, porque quizás se mueve en paralelo a estos espacios y tienen sus propios espacios y medios como es la oralidad popular, aunque también circulan en los medios de comunicación y en las tecnologías de la información -cine, literatura, internet-. En parte también porque abordan los grandes temas de la vida, y son expresión de reproducción, cambio o angustia existencial, de señalamiento del bien y el mal, de chivos expiatorios y relajamiento tensional, exorcizando incertidumbres, peligros, riesgos y miedos abstractos al aterrizarlos en determinadas historias y sucesos concretos.

\section{Imaginarios culturales y emocionales, expresiones narrativas y populares}

Partimos de una concepción de la cultura desde una óptica simbólica e interpretativa de la "realidad" construida por hombres y mujeres. La cultura es una urdimbre de significaciones, y su estudio, una ciencia interpretativa que busca explicaciones a partir de interpretar expresiones sociales (Geertz, 1986). Así en la cultura vemos la producción e intercambio de símbolos, y se investiga la constitución significativa de formas simbólicas en su contexto y estructura social que implica relaciones de poder y conflicto (Thompson, 1993).

Las significaciones son construcciones personales - sentimientos- y culturales -lenguaje y discurso-. En concreto existe una significación psicológica de afectos y cultural de creencias. De hecho, hay quien habla incluso de la personalidad cultural -prácticas y creencias(Benedit, 2003), y de la personalidad cultural básica (Kardiner, 1955). Las emociones están construidas culturalmente (Rosaldo, 1991). Las significaciones e imágenes culturales en el plano personal son construidas y animadas proyectivamente; los sí mismos y las emociones designadas culturalmente se remodelan introyectivamente a través de fantasías $y$ el mundo interior, inconsciente (Chodorow, 2003).

Imaginario es un concepto multisemántico según autores/as y enfo- 
ques, básicamente se entiende como imaginación, facultad de imaginar y resultado del proceso imaginativo (Banchs, Agudo Guevara, Astorga, 2007). De la definición de Durand (2000) nos quedamos con que imaginario son las imágenes mentales y visuales que manifiestan los valores e interpretaciones de la sociedad en el mundo. El sentido va más en cuando a organizar, expresar e interpretar, esto es, en un marco conceptual cultural. De la conceptualización de Castoriadis $(1975,1988)$ es importante destacar su sentido que se centra en cohesionar, orientar y animar, instituir en una palabra, nos interesa aquí lo del magma de significaciones que instituyen la sociedad, y son imaginarias porque no son racionales. Dentro de esto cabría tanto las expresiones culturales como las emociones sociales.

Entendemos por narrativas populares para el caso que nos ocupa las leyendas que se han contado y cuentan por generaciones verbalmente a través del habla, relatos populares en cuanto a que son compartidos por amplios sectores sociales, de creación anónima o sin autor/a inicialmente conocido, y populares también por su forma de transmitirse como parte de la tradición oral o lo que también se llama la oralidad popular: cuentos, oraciones, cantos, mitos y leyendas. En principio se trata de transmitir saberes y experiencias, a través de los géneros literarios narrativos.
Así, podemos llegar a afirmar que las narrativas culturales que estudiamos en estas páginas conforman una parte del imaginario social, en este caso de las personas que residen en la urbe $Y$ esto es así, en el sentido que muestran imágenes mentales y visuales, organizan y expresan valores existenciales e interpretan el mundo que se habita que diría Durand (2000). Pero también configuran el imaginario social, según la concepción más amplia y profunda de Castoriadis $(1975,1988)$, porque estos relatos reflejan, crean, condensan y reproducen o cambian un magma de significados que cohesionan y orientan, algo lejanos de la realidad y sobre todo la racionalidad, pero muy cercanos al mundo emocional de la psique y cultural de creencias y su expresión, aquí en forma de narrativas populares. Son también, o quizás es mejor decir que transportan representaciones sociales en este mismo sentido (Jodelet 1985). Crean y recrean, reflejan o reproducen, transforman o reinterpretan significaciones, pensamientos, sentimientos y actos. Reflejo y construcción de la vida individual y colectiva, sobre todo interpretativa e inter relacional en sociedad.

¿Y qué decir de las emociones y del giro que tiene lugar en las ciencias sociales sobre su apreciación actual, ya que tras años de olvido o negación -excepto en la psicologíahoy reaparecen con luz propia y son consideradas partes importantes, 
intrínsecas y dignas del estudio social?

En estas páginas consideramos que las leyendas son narraciones que reflejan creencias y surcan emociones, reproductoras del orden social hasta cierto punto, creadoras de identidad cultural, pero también una forma de transitar y quizás soltar miedos y de crear comunicación, cohesión y vínculo emocional. Si bien no es posible profundizar todo esto, sí se intenta ofrecer un breve panorama general sobre el tema. Una mirada interpretativa que invita, como se dijo, a la reflexión.

\section{Metodología}

Para lograr esto nos acompañamos de una encuesta aplicada a 900 personas habitantes de la Ciudad de México en el año 2013, cuyo cuestionario con preguntas abiertas y cerradas se centró en las leyendas tradicionales y las urbanas. Del total de la muestra, 436 fueron hombres y 464 mujeres. Las edades iban de los 7 a los 70 años y más, distribuidas de la manera siguiente: cien de 6 a 9 , cien de 10 a 13, cien de 14 a 18, cien de 19 a 29, cien de 30 a 39, cien de 40 a 49 , cien de 50 a 59 , cien de 60 a 69 , cien de 70 y más años. Todos/ as residentes en la Ciudad de México y de todas las delegaciones, $82 \%$ también nacidos en la ciudad, en segundo lugar, oriundos del Estado de México y luego de casi todos los estados de la República en un reducido porcentaje. El nivel educativo: primaria: $22 \%$; secundaria: $20 \%$; bachillerato: $10 \%$; universidad: $45 \%$. Sobre el sector laboral: trabajan en el público el 11\%; en el privado, $17 \%$; por cuenta propia, $7 \%$; en el hogar, $13 \%$; son estudiantes, $42 \%$ y jubilados, el 7\%. Y, finalmente, las personas encuestadas se consideran de nivel socioeconómico medio en general. Debe aclararse que no es una muestra representativa por lo que los resultados son inferencias de la misma y no del universo de la población. Con ello, lo que se logra es presentar ciertas tendencias de opinión sobre el tema que nos ocupa.

La pretensión es, como se dijo, mostrar algo de la importancia de las leyendas y su inserción en el medio social de manera general y panorámica, toda vez que presentar su relación con el mundo de las emociones y cómo éstas forman parte de la cultura. Por lo que más que centrarnos en los porcentajes exactos, lo haremos en las tendencias que los mismos indican. 


\section{Las leyendas tradicionales y contemporáneas}

La leyenda es una proyección de la realidad a través del cristal de la fantasía, una narración en la que coexisten la verdad y la ficción. Son materia de las leyendas los hechos, las acciones y las cosas que logran excitar la imaginación o que suscitan la agitación del ánimo. La leyenda surge como una relación coetánea o referente al asunto de que se trata, pero en el curso de su transmisión oral, mediante la cual se propaga, se le van introduciendo cambios y agregados que, lejos de desvirtuar su esencia, la enriquecen, pues lo substancial de ella es su linaje colectivo, su condición de relato forjado a lo largo de varias generaciones, abierto a toda aportación espontánea (Álvarez, 1998, p. 9).

Se considera que las leyendas tradicionales o antiguas, en general son relatos orales $\mathrm{y} / \mathrm{o}$ escritos en torno a acontecimientos históricos, míticos o fantásticos, y están inscritas en la tradición popular. Algunas narraciones hunden sus raíces en la historia, otras son de carácter fantástico, en todo caso son expuestas, la mayor parte de las veces como relatos verídicos o, mejor dicho, con intenciones de verosimilitud (Thompson, 1952; Degh, 1971; Scheffler, 1982).

Se trata de una "narración irreal, con huellas de verdad, ligada a un área o a una sociedad sobre temas de héroes, de la historia patria, de seres mitológicos, de almas en pena, de seres sobrenaturales" (CarvalhoNeto, 1969, p. 51). En dicho relato se precisan a veces el lugar, los nombres, las situaciones, con actos que parecen o son históricos y/o con calidad heroica.
Su intención utilitaria es de instruir, moralizar y distraer al mismo tiempo (Van Gennep, 1914). Poseen cierto valor documental, muestran costumbres, hábitos y la moral. Su forma es la de explicar hechos más o menos extraordinarios o sorprendentes, expuestos, como decíamos, como verídicos. Su función es, por un lado, colaborar en entender la conciencia colectiva de los componentes de una sociedad (Hand, citado por Lara Figueroa 1984); por el otro, la de ejercer una función práctica de aglutinante y cohesión social, además de ser recreación y entretenimiento (Degh, citada por Lara Figueroa, 1984). Se enmarcan en un ámbito sociocultural (Caro Baroja, 1989). Es por ello que hay narraciones muy arraigadas a su terruño que tienen que ver con la configuración e identidad de una comunidad local concreta en un espacio y un tiempo determinado, si bien vencen a este último y se reproducen a través 
del paso de los siglos, eso sí, únicas a veces en un espacio geográfico específico; mientras otras han migrado y se han difundido a los cuatro vientos, formando parte ya del patrimonio histórico de la humanidad.

La utilidad social y la naturaleza prescriptiva de la narrativa tradicional viene de muy antiguo: "La recitación de mitos y leyendas en la sociedad antigua y primitiva fue un rito indispensable" (Thompson, 1952). Se trata de lecciones de conducta y formas de iniciación moral (Van Gennep, 1914). Advertencia, enseñanza, vinculaciones de una comunidad con sus más preciados bienes, que posibilitan su perpetuación (Velasco, 1989). Además del carácter educativo para desarrollar un espíritu de observación de los rasgos de valor moral y de actos trascendentes y dignos de imitarse; constituye también, como ya se apuntó, un entretenimiento (Ibarra, 1943).

Es posible considerar que si el relato antiguo permanece vivo en la tradición oral de un pueblo, es porque todavía realiza alguna función (Malinowski, 1976). En todo caso, al ser recogido por escrito se puede indagar la intención de su creación y reproducción en el pasado y pistas en el presente, como parte de la herencia cultural de una sociedad o un pueblo determinado.

Existen también las denominadas leyendas urbanas, o, mejor aún. histo- rias legendarias de hoy, historias ejemplares, cuentecillos morales, mitos volantes o leyendas contemporáneas. Sencillas historias que pasan de boca en boca, que se crean anónimamente y se expanden rápidamente. "A diferencia de los géneros más clásicos como los cuentos maravillosos o las leyendas tradicionales, estas pequeñas historias, susceptibles de ser creídas, tienen hoy día una gran vigencia social" (Martí, 1994, p. 32). Son parte del folclore, entendid éste básicamente como acto comunicativo, con funciones de carácter mecánico y externas, y funciones psicológicas o internas (Pujol, 1986). Esto es, sirven o contribuyen desde la distracción de un momento en un grupo de gente o la inmovilización de un niño para que coma o duerma, mejorar la tranquilidad espiritual de un colectivo o individuo, o reflexionar en torno a una preocupación o problemática dada. Todo, como se aprecia, con un sentido similar a las consideradas antiguas leyendas.

Son breves y sencillos relatos de creación anónima que circulan en nuestra sociedad y que rápidamente se extienden entre la población en todo el mundo a través de diversos medios (Brednich, 1994) -últimamente también dentro de los modernos medios de comunicación, libros, películas, incluso internet-. Se centran en anécdotas a veces cotidianas, en transmisión de vivencias, pero con un componente extraordinario, guardan el rema- 
nente de imaginación, son parte de un contexto social determinado, como algunas de las leyendas tradicionales (Sánchez Carretero, 2001).

Comparten con ellas la característica de verosimilitud y autenticidad, pero en este caso más marcada, o más actualizada por las características del relato mismo, y tienen también la función práctica de explicar, aconsejar y prevenir, y de manera particular advierten de los peligros, o mejor dicho riesgos, actuales (Brednich, 1994). Hay quien las señala como administradoras del terror preventivo ante los peligros de la vida moderna (Pujol 1986). Combinan miedos y deseos, miedo a la técnica, a la violencia, a las drogas, a los poderes ocultos, a ideas angustiosas, permiten definir el peligro para exorcizarlo (Campion-Vicent y Renard 1992 cit. Ortí y Sampere, 2001).

Las leyendas urbanas son historias demasiado buenas para ser verdad. Estas fábulas populares describen acontecimientos presuntamente reales (si bien raros) que le han pasado a un amigo de un amigo. $Y$ generalmente las cuenta una persona fiable que las relata en un estilo creíble, porque realmente se las cree. Las localizaciones y los hechos que se describen son ciertos y conocidos (casas, oficinas, hoteles, centros comerciales, autopistas, etcétera) y sus personajes humanos, personas muy normales. Sin embargo, los incidentes cómicos, chocantes $u$ horripilantes que les ocurren a estas personas llegan demasiado lejos para ser creíbles. (Harold Brunvand, 2002, p. 15)2.

Es importante mencionar que este tipo de narraciones traspasa fronteras, y se pueden encontrar en el otro extremo del planeta con los mismos argumentos o con cierta variedad de circunstancias, aunque las hay también de carácter autóctono. Se trata de narraciones nómadas e itinerantes. “...las han sentido contar a un amigo de un pariente o amigo de los protagonistas" (Pujol, 198, p. 18).

Eso sí son, repetimos, de cuño reciente, lo cual comprueba que la leyenda sigue viva, si bien el contenido relacionado con lo sobrenatural y como explicación del mundo ya no mantiene su vigencia, ahora se centran más en anécdotas cotidianas -aunque con asuntos raros y cuestiones sorprendentes-, y en transmisión de vivencias. Pero guardan el remanente de imaginación, y por supuesto, son parte de un contexto social determinado, de ahí que responden en ocasiones a coyunturas socioeconómicas o políticas bien concretas -desconcierto, confusión e inseguridadsimples miedos humanos - eternos o concretos, reales o fantasiosos- y la 
necesidad de disolverlos a través de la magia de la palabra, de sacarlos y expresarlos, soltarlos y quién sabe si también exorcizarlos.

Tanto leyendas tradicionales como urbanas combinan cultura y emoción, y ambas tienen una función social más allá del divertimento, que tiene que ver con la memoria, la historia, las creencias, la comunicación, las percepciones, las emociones, las necesidades, la comunicación y la expresión.

\section{Resultados, la tradición oral en la era global}

Pensar la tradición oral como un mecanismo que ancla y construye nuevas representaciones sociales y es al mismo tiempo una representación social, llevó a considerar el papel articulador de la tradición oral como una bisagra que moviliza adentro y afuera las representaciones compartidas en una comunidad. La tradición oral será, entonces, el espacio simbólico que condensa, genera, negocia y lucha en el campo de la vida cotidiana con las nuevas representaciones globales (Lepe Lira, 2006, p. 39).

La tradición oral está viva y presente en México como mostraremos a continuación. Aquí analizamos dos cuestiones básicas de la encuesta presentada con anterioridad. En primer lugar, exponer el contexto de reproducción de las leyendas antiguas y urbanas, y una comparación sobre el tema. En segundo lugar, tras seleccionar una mínima muestra de las leyendas más conocidas y relatadas, se reflexiona en cuanto a su posible significado y función social a la luz de sus expresiones culturales y reacciones emocionales, a modo de una interpretación de las mismas.

\section{Contexto de reproducción de las leyendas urbanas y tradicionales}

Para empezar, revisaremos afirmaron que la leyenda tradiel contexto de reproducción de cional fue relatada por una persona: las leyendas: ¿Quién te la contó? ¿Dónde la escuchaste? ¿Cuántos años tenías en ese momento? ¿Te gustó? En cuanto a quién se la contó, la mayoría de las y los entrevistados el $84 \%$. El $47 \%$ respondió afirmativamente para la urbana o contemporánea -en general, a través de un familiar-. En segundo lugar, a bastante distancia, la conocieron a 
través de la televisión-en el caso de la urbana-, y en tercero, un libro o el radio. El segundo lugar para la tradicional fue un libro, seguida por televisión y radio (Cuadro 1). Ambos tipos de leyenda se transmiten todavía en nuestros días y mayoritariamente a través de la palabra enunciada y pronunciada, la relación cara a cara e interpersonal, lo cual prueba lo que se dijo con anterioridad y seguiremos afirmando, de cómo está viva hoy la tradición oral en México.

Cuadro 1 ¿Quién te la contó? \%

\begin{tabular}{lcc}
\hline Leyenda & & \\
\hline & Tradicional & Urbana \\
Persona & 84 & 47 \\
Libro & 8 & 3 \\
Televisión & 3 & 17 \\
Radio & 1 & 3
\end{tabular}

Fuente: Cuestionario sobre leyendas, elaboración propia.

Cuadro 2 ¿Dónde la escuchaste? \%

\begin{tabular}{|c|c|c|}
\hline \multicolumn{3}{|l|}{ Leyenda } \\
\hline & nal & Urbana \\
\hline Casa & 68 & 52 \\
\hline Escuela & 15 & 8 \\
\hline Calle & 2 & 3 \\
\hline
\end{tabular}

Fuente: Cuestionario sobre leyendas, elaboración propia.

Respecto a dónde la escucharon,y en correlación con la pregunta anterior, la casa - donde habita la familia y ven la televisión o leen libros- es el lugar privilegiado, con $68 \%$ de personas que así respondieron para la leyenda tradicional y $52 \%$ para la urbana. Si bien la escuela y la calle también aparecen como otra opción (Cuadro 2).

Sobre la edad en que la escucharon la mayoría fue en la infancia y la adolescencia. En general, de los 5 a los 15 años, la tradicional; la urbana, de los 7 a los 15. Nótese cómo la tradicional se transmite desde una edad más temprana y, además, concentra a la mayoría de la población en un tramo determinado, lo que demuestra nuevamente la importancia y el peso de las antiguas leyendas en nuestro país y en nuestros días. Por su parte, la urbana tiene un patrón etario de transmisión-recepción más amplio y disperso. No sólo se la conoce a mayor edad, sino que también es de más reciente creación, y finalmente hay quien no la detecta como leyenda, siendo considerada un rumor o, incluso, un hecho real.

Otro interrogante giraba en torno a si la leyenda en cuestión les gustó o no. En general, podemos decir que la respuesta fue afirmativa, no obstante, hay que apuntar las diferencias, entre la leyenda tradicional que agradó a $76 \%$, mientras que la urbana a $44 \%$. Por el contrario, entre quienes dicen que no les gustó, la urbana duplica a la tradicional. Mientras tanto, la respuesta "regular" es igual para unas y otras (Cuadro 3). Parece ser que las antiguas leyendas siguen gozando del agrado de la gente. 
Cuadro 3 ¿Te gustó? \%

\begin{tabular}{lcc}
\hline Leyenda & & \\
\hline & Tradicional & Urbana \\
Sí & 76 & 44 \\
No & 11 & 22 \\
Regular & 11 & 11 \\
\hline
\end{tabular}

Fuente: Cuestionario sobre leyendas, elaboración propia.

Cuadro 4 ¿Qué sentiste cuando te la contaron? \%

\begin{tabular}{lcc}
\hline Leyenda & & \\
\hline & Tradicional & Urbana \\
Temor & 41 & 21 \\
Nada & 8 & 11 \\
Intriga & 7 & 6 \\
Tristeza & 6 & 5 \\
Interés & 6 & 2 \\
Emoción & 5 & 3 \\
Impresión & 4 & 3 \\
Alegría & 2 & 5
\end{tabular}

Fuente: Cuestionario sobre leyendas, elaboración propia.

¿Qué sentiste cuando te la contaron? El sentimiento ${ }^{3}$ más destacado por sobre todos es el temor o miedo, $41 \%$ para las leyendas tradicionales y $21 \%$ para las urbanas. Sin embargo, hay también un número y porcentaje importante que dicen no haber sentido nada. Luego aparecen otros sentimientos, como la alegría y la tristeza pero en menor medida, así como algunos conceptos afines en la órbita semántica de los sentimientos, tales como intriga, emoción, impresión (Cuadro 4).

Resumiendo, la transmisión de las leyendas, sean tradicionales o urbanas, llega en su mayoría a través de la familia, de forma oral, cara a cara y en el hogar, durante los años de infancia y primera juventud 0 adolescencia. En general, puede decirse que las leyendas agradaron, pero más las tradicionales que las urbanas. El sentimiento predominante y más común a la hora de escucharla fue el temor, casi el doble para las tradicionales que para las urbanas. En todo caso, para unas y otras este sentimiento es el que predomina hoy como ayer, con lo cual conviene tomar nota. También es posible pensar que el agrado o desagrado de una leyenda o se relaciona con el mayor o menor temor o miedo que esta produzca. Es más podría hacerse la interpretación inversa con base a los datos recabados, esto es, agradan más la que más temor producen. Si bien en este agrado puede haber otras causas culturales que no se pueden presentar con los datos recabados en el trabajo realizado.

\section{Leyendas en concreto: enunciación}

Las leyendas narradas son muchas y muy diversas, vamos a revisar su significación y función hasta donde se pueda y según nuestra interpre- 
tación. Las tradicionales fueron 291, mientras que las urbanas, 360 , reagrupando las diferentes narraciones y versiones de una misma leyenda. Ante la imposibilidad de traerlas todas a estas páginas, se muestra el cuadro 5 en el cual presentamos los casos de aquellas que fueron expuestas por 10 o más personas, todo traducido en porcentajes. Como curiosidad, debemos mencionar que fue la narración de La Llorona la más numerosa entre las leyendas tradicionales y la segunda expuesta en las urbanas, lo cual nos da la medida de cómo está presente en el México de nuestros días. Otra cuestión que se desea comentar es que en las leyendas tradicionales todas las narradas son realmente antiguas leyendas y si, por ejemplo, El Jinete sin cabeza se puso de moda tras la película, ya existían versiones anteriores autóctonas en la imaginación popular en el país. En cuanto a las leyendas urbanas, se nombra, no sólo a La Llorona que es esa sí y sin lugar a dudas tradicional, sino también a
La Planchada, que también puede ser considerada en cierta forma tradicional y muy popular desde el pasado siglo, o El Coco, que más que leyenda es un personaje legendario con versiones diversas que tradicionalmente se usan con la infancia desde muy antiguo y en muchos lugares del mundo. Pero, además, en el caso de El Chupacabras más bien podría ser considerado como rumor. El Mochaorejas fue, por desgracia, un caso de la vida real. Chucho El Roto una leyenda típica de héroe popular. Y Cañitas o La Casa de Cañitas como también se la denomina, se trató de una película basada en un libro sobre unos hechos supuestamente reales y que estuvieron muy extendidos en los medios, entre ciertos grupos juveniles y en los últimos años. No obstante, todo lo dicho, a la hora de elaborar el cuadro correspondiente se respetó lo considerado por la población consultada respecto de cuáles eran leyendas tradicionales y cuáles urbanas.

Cuadro 5 Relata brevemente una leyenda actual \%

\begin{tabular}{lrlr}
\hline Leyenda tradicional & \multicolumn{3}{c}{ Leyenda urbana } \\
\hline La Llorona & 35.1 & El Chupacabras & 15.9 \\
Los volcanes & 7 & La Llorona & 2.7 \\
El Callejón del beso & 5.8 & Cañitas & 2.5 \\
La mulata de Córdoba & 2.6 & La Planchada & 2 \\
El Jinete sin cabeza & 2.1 & Chucho el roto & 1.3 \\
El Nahual & 1.4 & El Mochaorejas & 1.2 \\
& & El Coco & 1.1 \\
\hline
\end{tabular}

Fuente: Cuestionario sobre leyendas, elaboración propia. 
De nuevo y ante la imposibilidad de traer a estas páginas todas las leyendas recabadas ni las versiones que suman en total $1.800-900$ tradicionales y 900 urbanas-, se han seleccionado algunos relatos que consideramos ilustrativos de las más mencionadas, y traemos unas cuantas de niños/as y de jóvenes de entre 8 y 18 años de edad, con objeto de tener un recorte etario concreto. Eso sí, se transcribieron narraciones de las más populares, conocidas y en mayor cantidad relatadas: $L a$ Llorona, Los volcanes, El Callejón del beso, La Mulata de Córdoba, entre las tradicionales; y de las urbanas, El Chupacabras, Cañitas, La Planchada, El Mochaorejas, El Coco y Chucho el roto. No analizaremos los relatos, reiteramos que se trata de ejemplos, no obstante se constata la diversidad de las fuentes de imágenes y relatos. $Y$ también tanto por el número de veces que fueron relatadas, como y el tono de la narración obtenida ilustran en alguna manera y de alguna medida la interpretación y reflexión que realizamos a continuación.

\subsection{Leyendas antiguas}

\section{La Llorona:}

Había una vez una señora con tres hijos y un esposo. Eran muy felices, hasta que una noche con truenos llegó el papá y trajo maldad; y la mamá se volvió loca y mató a sus tres hijos y los echó a un río; y el papá la mató y el espíritu dice por donde hay ríos en la noche: " $\mathrm{A} A y$ mis hijos!" (Niño, 8 años).

Una señora estaba con sus hijos, y de repente llega su esposo y le dice que se va a ir de la casa. Ella, de la desesperación, ahogó a sus hijos y dicen que su alma anda vagando, llorando arrepentida. “¡Ay mis hijos!” (Niña, 13 años).

\section{Los volcanes:}

Era un joven guerrero que se Llamaba Popocatepetl y estaba enamorado de la hija del rey, Iztaccíhuatl, y ella también estaba enamorada de él, pero un día Popocatépetl tuvo que ir a la guerra y otros soldados le dijeron a Iztacihuatl que él había muerto. Pero no era verdad. Ella estaba muy triste y murió y cuando Popocatépetl volvió, la encontró y se la llevó y nunca más supieron las demás personas qué había pasado. Después aparecieron dos volcanes y los ciudadanos dijeron que era el joven Popocatépetl e Iztaccíhuatl (Niña, 12 años).

Había un príncipe que fue mandado a la guerra, su esposa se quedó esperándolo en la punta de una montaña, el Iztaccíhuatl. Ella de tanto esperar y del frío, se quedó dormida, la nieve la cubrió. Cuando el príncipe regresó vio 
que estaba enterrada y muerta, el príncipe se sentó a llorar en la punta del Popocatépetl y así murió llorando por ella (Niño, 16 años).

\section{El Callejón del beso:}

Ana era una joven rica y española que vivía en la ciudad de Guanajuato. Carlos era un pobre minero. Se conocieron y se enamoraron. Carlos vivía frente de la casa de Ana en un cuarto muy pobre al final del callejón. El padre de Ana, al darse cuenta del romance, le prohibió verse con Carlos. Una noche, se vieron en el balcón en frente de sus casas y se besaron; y, al verlos, el papá de Ana le disparó, y murió Ana estirando la mano hacia su amado (Niña, 9 años).

En Guanajuato, en una calle pequeña, las ventanas de sus balcones estaban casi juntas. Eran un hombre y una mujer. Los dos se enamoraron, pero el padre de la chava no quería a los tipos como ese, ya que era un humilde herrero. Entonces, una noche que se iban a fugar, el padre de la novia lo mató y la mujer se mató y dicen que su alma deambula por ahí (Niña, 15 años).
La mulata de Córdoba:

La mulata de Córdoba tenía el don de aparecer de repente si la invocaban, ayudaba a novios ambiciosos. Era poderosa y decían que era la consentida del diablo. Un día, la inquisición la encerró y cuando la iban a castigar, el carcelero vio que estaba pintado un barco en la pared. El carcelero vio cómo la mulata, riéndose, desapareció en el barco (Niña, 9 años).

\section{El Jinete sin cabeza:}

Existía un guerrero que siempre en las batallas cortaba las cabezas de sus enemigos. Una vez lo iban persiguiendo unos soldados; el guerrero se metió al bosque cuando de pronto encontró a dos niñas que estaban recolectando varas. El guerrero les pidió que guardaran silencio, pero una rompió una vara y los soldados lo encontraron y le cortaron la cabeza. Los soldados se llevaron el cuerpo y la cabeza se la quedó la niña bruja. Desde ese día, la bruja controlaba el cuerpo por medio de la cabeza, ordenando que matara a la gente (Niño, 12 años). 


\subsection{Leyendas urbanas}

El Chupacabras:

Se creen en un pueblo al sur que un animal muy raro con ojos saltones y garras filosas y colmillos grandes. Por las noches, en la oscuridad, salía y les chupaba la sangre a sus víctimas. En ocasiones, eran personas. Dicen que era tan feo que a la llegada de la noche los lugareños temblaban de miedo y le pedían a Dios que no apareciera el Chupacabras (Niño, 8 años).

Se dice que era un animal que le chupaba la sangre a las cabras y esto sucedía en el norte del país. Y así duró esta leyenda durante varios meses y seguían apareciendo cabras muertas. Jamás se supo que fue lo que las atacaba (Niño, 9 años).

\section{Cañitas:}

En 1984 una familia se reunió para jugar a la Ouija, pero se supone que liberaron un espíritu y ese espíritu maligno se encarga de matarlos a todos. A la nana le empezó a absorber energía hasta que muere y a uno de los hijos lo empuja de la ventana, y hasta que sólo queda uno, que era el papá, que es el que escribe el libro (niño, 13 años).
La Planchada:

A una amiga, el año pasado la operaron de las anginas y nadie de su familia la iba a visitar. Entonces estaba llorando y un día entra una señora al cuarto. Esta señora era una enfermera de pelo negro, blanca y muy amable. Después, a mi amiga le dio su medicina y le dijo que no se preocupara y se fue despreocupada, pensó llegó en el momento adecuado a ayudarla. Después llegó la enfermera que le tocaba y le preguntó si le habían dado su medicina y le dijo que sí y ella nunca entró (Niña, 11 años).

Una enfermera que murió en el terremoto del 85 , y dicen que hoy en día ayuda a curar a los enfermeros y ellos le aceptan la medicina y todo. Pero en los hospitales no la conocen o sólo la ven enfermos y algunos doctores (Niña, 14 años).

El Mochaorejas:

Un hombre que secuestraba a las personas y, como muestra de que era capaz de todo si no pagaban el rescate, les cortaba una oreja a sus víctimas y las enviaba a sus familiares (Niña, 9 años). 
Los niños que no se duermen temprano se los lleva El Coco, también si un niño se porta mal, El Coco se lo llevará (Niña, 10 años).

Cuando los niños no se quieren dormir en la noche, o que ya estaban dormidos, les jalaba los pies; luego a los niños que se burlaban del Coco los asustaba y los dejaba paralizados y traumatizados y por eso se canta acá, los niños se duermen temprano y no se burlan más del Coco (niño, 11 años).
Un hombre que robaba a las personas ricas para darles dinero a los pobres. Todas las personas a las que ayudaba lo querían mucho y protegían de las autoridades y de los ricos que lo querían matar. Para su desgracia, se enamoró de una mujer rica y eso fue su perdición. Su historia fue contada de boca en boca y de generación en generación, por eso se convirtió en una leyenda (Niña, 13 años).

\section{A modo de discusión y conclusión: significación y función}

Y así llegamos a la interpretación y reflexión sobre algo de lo mostrado en estas páginas. Desde un inicio partimos, como se dijo, de una concepción de la cultura como interpretación simbólica de significados a través de las expresiones y narrativas sociales. Este carácter interpretativo de la vida social descubre patrones de significado incorporados a formas simbólicas, explica interacciones, producción e intercambio, y profundiza en torno a símbolos arraigados en determinados contextos y estructuras que implican relaciones de poder, desigualdad y conflicto (Thompson, 1993; Geertz, 1986), entre otras cosas. Además, y por supuesto, del reflejo emocional de las narrativas culturales y de su uso precisamente con objeto de transitar emociones - como el caso del miedo-y de crear vínculos afectivos -el sentirse unidos-

Tras la revisión de definiciones conceptuales, contextualización de relatos legendarios y la enunciación de su mismo contenido, concluimos con la idea central, apuntada inicialmente, de que las leyendas entretejen cultura y psique. Constituyen un entramado de significados que tienen que ver con estrategias de tipo social y cultural, toda vez que con mecanismos subjetivos y psicológicos del mundo emocional. Son imaginario (Castoriadis, 1975) a la vez 
que representación social (Moscovici, 1979). Unen y comunican, institucionalizan y expresan. De hecho, se podría afirmar que todas las formas de creación humana son imaginarias $y$ que elaboramos conocimiento y nos comunicamos a través de representaciones sociales.

La diversidad de las leyendas urbanas es amplia, toda vez que se entreteje a hechos reales, vestigios de historias verdaderas, ecos de rumores populares. En todo caso, lo que podría unificar es la existencia de seres -personas, espíritus o espantos desconocidos e indescriptibles- buenos y malos - más malos que buenos-, pero cuya dimensión sobrenatural produce, en principio, temor. Así, los y las protagonistas de estas historias están ahí para crear un estado de ánimo o sentimiento de fondo de inseguridad o miedo - o también es posible pensar que para expresarlo, proyectarlo, soltarlo, reproducirlo, intensificarlo, o simplemente sentirse más vivo/a- y por lo tanto lo que se precisa o se tendría que perseguir sería el cuidarse y protegerse como necesidad para satisfacer la emoción aparentemente considerada como negativa, toda vez que se observa advertencia de comportarse bien en general como lo manda la sociedad o el discurso de moralidad con objeto de no sufrir consecuencias indeseadas -claramente ejemplarizadas en los relatosSi bien, entre El Mochaorejas y El Coco hay un gran abismo aparentemente, los miedos reales e imaginarios o fantaseados, o sólo imaginarios pero verdaderamente sentidos, que no es lo mismo pero al final de cuentas es igual, muestran y dan cuenta posiblemente de una sociedad temerosa, asustada, desprotegida -podríamos añadir que dicha sociedad proyecta, - que busca culpables y chivos expiatorios, o pretende seguir introyectando el temor a través de la reiteración de las narraciones la endoculturación primaria- La Mulata de Córdoba y El Jinete sin cabeza o el Nahual, por citar algunas de las antiguas leyendas más mencionadas, nos hablan de poderes especiales, sobrenaturales, inasibles e incomprensibles, por seres aparentemente negativos o así designados desde la cultura oficial: brujas y nahuales - no discutiremos sobre este punto-. Ello es una muestra de cómo la población se siente desprotegida ante el poder, impotente frente a ciertos seres o determinadas situaciones que la rebasan y atemorizan. La Planchada, personaje ambivalente, pues sana y cuida, pero también puede espantar, es parte de la inseguridad y actitud ambigua que la población percibe ante la ciencia médica, por ejemplo - que podría codearse con varios rumores en tiempos de la influenzaTambién entre El Chupacabras y el espíritu maligno de Cañitas hay distancia, rumores generales y extraños que llegan de lejos o una historia literaria y fílmica concreta con calle, número y casa, no es menos cierto que es el miedo a lo desco- 
nocido, lo sobrenatural, lo incomprensible, una proyección quizás de miedos más próximos, sociales y/o personales pero en sociedad, de la incomprensión y desconocimiento ante la naturaleza de la existencia o las posibilidades de riesgo presentes en la cotidianeidad actual, que tanto la leyenda como el rumor expresan, intensifican y/o exorcizan, pero que, en todo caso, reflejan desasosiegos concretos o eternos. Varios de ellos posiblemente relacionados con la muerte, ya que ésta constituye el miedo primigenio, intrínseco al ser humano y de nuestra sociedad, como sabemos según enfoques psicológicos, pero y también en época reciente desde las mismas ciencias sociales en general (Bauman, 2007). Muerte por un ser desconocido o fantástico, muerte a manos de un malvado espíritu, muerte por un criminal, la diferencia no es mucha, al final del camino todo mundo nos toparemos inexorablemente con la muerte. La muerte es, al fin y al cabo, lo único seguro en nuestras vidas personales y la que nos iguala.

Sobre el contexto de reproducción social, nos quedan las cosas claras: las leyendas, tanto tradicionales como urbanas, circulan en la oralidad popular, de forma directa en circunstancias cara a cara o de boca a oído, son las personas y la familia, quienes las transmiten de manera mayoritaria a pesar que hay otros medios. La casa es el lugar por exce- lencia donde se contacta con este tipo de narraciones sociales y a corta edad, generalmente en la infancia y la adolescencia. Suelen gustar y el sentimiento que impera es el temor. Observamos que con sus diferencias, el contraste de reproducción social de los dos tipos de leyendas aquí estudiados, guarda ciertas similitudes tendenciales que deseamos subrayar.

En cuanto a significados y funciones sociales, no todo está tan claro, pero es posible esbozar algunas conclusiones: ambos tipos de leyendas parecen conducir, con sus expresiones culturales y vivencias emocionales, a una estructura narrativa que puede ser también interpretada como semejante. Son relatos raros, con hechos sorprendentes o anécdotas cotidianas, con componentes extraordinarios, expuestos como verídicos y que a fuerza de reiterarse parecen ya familiares y lo que es más importante sino veraces con tintes de veracidad. Por otro lado, tanto las leyendas antiguas como las contemporáneas poseen un valor documental, son un texto (Geertz, 1986) y exponen formas simbólicas (Thompson, 1993). Con su revisión es posible desentrañar, desde hábitos y costumbres hasta el ámbito sociocultural, pasando por cierto código moral que las atraviesa. Pero lo que es más destacable, no sólo cubren la función de recrear, entretener, distraer o divertir, lo que realmente es 
importante es como funcionan como medio de conocimiento y comunicación -como señalábamos en un inicio (Gutiérrez y Plantin, 2010)-, con objeto de reflexionar y entender la conciencia social colectiva, ante preocupaciones y/o problemas - latentes u obvios - o como se definen algunas posibilidades de peligros de siempre o riesgos de la vida actual. Previenen, toda vez que advierten y aconsejan en general desde cierto discurso moral, entre enseñanza y amenaza. Todo esto como parte de la expresión cultural que está indisolublemente ligada a lo emocional. $Y$ en este sentido, reflejan, reproducen o descargan miedos, reales o imaginarios poco importa, los comparten y exorcizan, los introyectan o proyectan, en todo caso los transitan y elaboran más o menos terapéuticamente 0 , de la mejor manera posible, que parecen encontrar para el caso, que es la creación y reproducción de las leyendas, su transmisión y el compartirlas. Por supuesto, y como desde un inicio se dijo, esto es sólo una mirada o una interpretación, pero es la mirada que aquí consideramos como explicación más aproximada a la realidad, y que ilustra la importancia de las leyendas vivas como cauce de comunicación, como parte de la cultura y como medio para expresar las emociones, toda vez que socialización y distracción también.
Todo lo cual aúna aspectos sociales, culturales y emocionales, interrelacionales, grupales, psíquicos y sociales, como se apuntó al principio. En su vertiente comunicacional dan significados a algunos cambios y recrean las vivencias de identidad y pertenencia, reconfortan emociones y mantienen relaciones intersubjetivas, es decir, unen y contienen, social y afectivamente hablando. Éste es tal vez un aspecto poco apreciado y señalado en las leyendas y que aquí queremos dejar claro y subrayar. Quizás por todas las cuestiones expuestas con anterioridad, es que esta narrativa oral de leyendas tradicionales y contemporáneas está vigente. Quizás también porque, ante las inseguridades y temores que hoy nos rodean, no encontramos respuesta en los grandes mitos, las sagradas religiones, las teorías con mayúsculas, los avances de la tecnología y la ciencia, y hay que echar mano de relatos entre cotidianos y extraordinarios, fantásticos y hasta reales en algunos casos, que ofrezcan, como se dijo, la sensación de desahogo o de contención ante la angustia existencial de ayer, de hoy y de siempre, y los nuevos miedos, pequeños y grandes, personales y colectivos, reales o imaginarios de los nuevos tiempos que corren, sus realidades y sus retos. 


\section{Referencias bibliográficas}

- Álvarez, J. R. (1998). Leyendas mexicanas. León: Everest.

- Banchs R., María A., Agudo, Á. y Astorga, L. (2007). “Imaginarios, representaciones y memoria social". En Arruda, M. y M. de Alba (Coords.), Espacios imaginarios y representaciones sociales. Aportes desde Latinoamérica (pp. 45-93). Barcelona: Anthropos.

- Bauman, Z. (2007). Miedo líquido. Barcelona: Paidós.

- Benedict, R. (1967). El hombre y la cultura. Investigaciones sobre los orígenes de la cultura. Buenos Aires: Sudamericana.

- Brednich, R.W. (1994). “'Laranya a la iuca. Llegendes urbanes d'avui”. Revista d'Etnologia de Catalunya, (4), 34-43.

- Caro, J. (1989). De los arquetipos y las leyendas. Barcelona: Círculo de Lectores.

- Carvalho-Neto, P. (1969). Historia del folklore iberoamericano. Santiago de Chile: Editorial Universitaria.

- Castoriadis, C. (1975). La institución imaginaria de la sociedad. Vol. 1. Marxismo y teoría

- revolucionaria. Barcelona: Tusquets Editores.

- Castoriadis, C. (1988). Los dominios del hombre: las encrucijadas del laberinto. Barcelona: Gedisa.

- Chodorow, N.J. (2003). El poder de los sentimientos. La significación personal en el psicoanálisis, el género y la cultura. Buenos Aires: Paidós.

- Degh, L. (1971). Procesos de formación de leyendas. Buenos Aires: Mecanografiado.

- Durand, G. (2000). Lo imaginario. Barcelona: Ediciones del Bronce.

- Geertz, C. (1986). La interpretación de las culturas. Barcelona: Gedisa.

- Gutiérrez, S. y Christian P. (2010). “Argumentar por medio de las emociones. La campaña del miedo del 2006”. Versión, (24), 41-69.

- Harold,J. (2002). El fabuloso libro de las leyendas urbanas. Demasiado bueno para ser cierto. Barcelona: Alba Editorial.

- Ibáñez, T. (1988). “Representaciones sociales. Teoría y método”. En T. Ibáñez (Coord.), Ideologías de la vida cotidiana (pp. 153-216). Barcelona: Sendai.

- Ibarra, A. (1943). "El cuento en México”. Anuario de la Sociedad Folklórica de México. 
- Jodelet, D. (1985). La representación social: fenómeno, concepto y teoría. En S. Moscovici (Comp.) Pensamiento y vida social. Psicología Social II (pp. 469-494). Barcelona: Paidós.

- Kardiner, A. (1955). Fronteras psicológicas de la sociedad. México: FCE.

- Lara, C. A. (1984). Leyendas y casos de la tradición oral de la ciudad de Guatemala. Guatemala: Editorial Universitaria.

- Malinowski, B. (1976). Una teoría científica de la cultura. Buenos Aires: Sudamericana.

- Martí, J. (1994). “Presentació. Llegendes urbanes d’avui”. Revista d’Etnologia de Catalunya, (4), 32-34.

- Moscovici, S. (1979). El psicoanálisis su imagen y su público. Buenos Aires: Huemul.

- Thompson, S. (1952). "La leyenda”. Folklore Americano, XII (1), 25-29.

- Ortí, A. y Sampere, J. (2001). Leyendas urbanas en España. Barcelona: Martínez Roca.

- Pujol,J. M.(1986).“Històries extraordinàries, llegendes urbanes”. Perspectiva Escolar, (102), 18-20.

- Rodrigo M. y Medina, P. (2010). “La recepción mediática de las emociones”. Versión, (24), 147-172.

- Rosaldo, R. (1991). Subjetividad en el análisis social. Cultura y verdad. Nueva propuesta de análisis social. México: Grijalbo.

- Sánchez, C. (2001). “Llegendes urbanes i minories”. Revista d Etnologia de Catalunya, (19), 86-99.

- Scheffler, L. (1982). Cuentos y leyendas de México. Tradición oral de grupos indígenas y mestizos. México: Panorama.

- Thompson, J. B. (1993). Ideología y cultura moderna. Teoría crítica social en la era de la comunicación de masas. México: UAM-X.

- Van, A. (1914). La formación de las leyendas. Madrid: Librería Gutenberg.

- Velasco, H. M. (1989). “Leyendas y vinculaciones”. En J. P. Etienvre (Coord.), La leyenda:

- antropología, historia, literatura. Actas del coloquio celebrado en la Casa de Velázquez (pp. 115-132). Madrid: Universidad Complutense. 


\section{Notas}

1 Nos gustaría presentar estas ideas a modo de hipótesis, pero ante la imposibilidad de probarlas o refutarlas fehacientemente, sólo las esbozamos como guías de la investigación, sin pretender dar una respuesta o explicación de los hallazgos del estudio frente a las mismas; pero sí elaborar una reflexión al respecto.

2 Las leyendas urbanas han permeado la cultura popular en nuestros días, y se pueden leer en la prensa diaria, en la literatura, la televisión, la cinematografía, en el radio, y por supuesto, en Internet (Brunvand, 2002). Últimamente llegan en cadenas, vía correo electrónico o redes sociales, o las sigue contando la gente a viva voz.

3 Usamos indistintamente emoción y sentimiento en este trabajo. No obstante, stricto sensu, consideramos que la emoción es la reacción fisiológica y el sentimiento, lo nombrado que permanece en el tiempo, dicho de forma muy resumida y esquemática. 